Несовершенный остеогенез (НО) представляет собой редкое генетическое заболевание соединительной ткани, вызванное в подавляющем большинстве случаев мутациями в генах COL1A1 и COL1A2, ответственных за синтез коллагена 1 типа, которое приводит к развитию множественных переломов костей и прогрессирующим деформациям скелета из-за дефицита коллагена I типа. Известно 15 типов НО, из которых наиболее тяжелым течением отличается II тип НО в виду 100\% смертности больных в неонатальном или перинатальном периодах. Структура смертности при других типах НО мало изучена в виду гетерогенности клинической симптоматики и тяжести поражения соединительной ткани. В статье приводится описание клинического случая НО III типа, осложненного генерализованным остеопорозом с множественными переломами тел позвонков и трубчатых костей и выраженным кифосколиозом, обусловившим летальный исход.

КЛЮЧЕВЫЕ СЛОВА: Несовершенный остеогенез; Остеопороз; Смертность; Бисфосфонаты; Деносумаб; Клинический случай

\title{
OSTEOGENESIS IMPERFECTA AS A CAUSE OF DEATH
}

(c) Anastasia A. Malygina, Tatiana A. Grebennikova, Anatoliy N. Tiulpakov, Zhanna E. Belaya

Endocrinology Research Centre, Moscow, Russia

Osteogenesis imperfecta $(\mathrm{OI})$ is a rare heterozygous connective tissue disordercaused by mutations in genes that affect collagen components (in most cases mutations in COL1A1 и COL1A2 genes). The current classification system includes 15 types of OI, one of which (type II) is characterized by $100 \%$ intrauterine or perinatal mortality. The structure of mortality in other Ol types is poorly understood because of the heterogeneity of clinical symptoms and the severity of connective tissue damage. W present a clinical case of type III osteogenesis imperfecta, complicated by generalized osteoporosis with multiple fractures of vertebrae and tubular bones and progressive kyphoscoliosis. Late-initiated treatment led to progression of the disease and led to cardiopulmonary insufficiency and death of the patient. Our clinical case highlights the importance of timely diagnosis, treatment and regular observation in patients with OI.

\section{KEYWORDS: Osteogenesis imperfecta; Osteoporosis; Mortality; Case report}

\section{INTRODUCTION}

Osteogenesis imperfecta (OI) is a hereditary connective tissue disease in most cases caused by mutations in the COL1A1 and COL1A2 genes which are responsible for the synthesis of type 1 collagen [1-4]. In addition to classical I-IV types of OI by D.Sillence [5] classification, there are 15 known types of the disease [6]. Clinically, the OI is characterized by severe bone fragility with a tendency to low-trauma fractures, joint hypermobility, blue sclera, dental abnormalities and hearing loss [7]. According to statistics in the USA and Canada, the incidence of OI is 1: 10,000-20,000 cases [8,9].

Ol Type I is the most common type of the disease; it is characterized by mild clinical picture, as fractures do not occur after puberty due to complete ossification. As the adulthood setsWhen the patients reach adulthood, their BMD becomes equal to populational, with mean life expectancy slightly decreased due to the risk of fatal fractures during childhood [10]. Type II OI is a perinatal lethal form of the disease, characterized basiliar skull fractures, vertebral and long tubular bone fractrures, and decreased lungcapacity. Patients with type II OI die within 1 year of life due to pulmonary insufficiency or cerebral hemorrhage [11].Among non-lethal forms of the disease, Ol type III is the most se- vere, characterized bymultiple fractures and progressive bone deformities. The average life expectancy of type III Ol patients is decreased, compared with the populational level -approximately 30 years [11]. In type IV OI, the severity of clinical picture may vary from mild (as IO type I) to severe (as type III). Life expectancy in mild forms of the disease usually does not differ from general population, and in severe cases it is slightly lower [10].

\section{CASE DESCRIPTION}

Patient I. admitted to Endocrinology Research Centre in November 2014 at the age of 36, complaining of periodic back pain, frequent atraumatic fractures (up to 10 per year), partial hearing loss.

At admission, the first thing to notice was the patient's appearance: he had a disproportional short stature with a shortening and deformation of upper and lower extremities, pronounced kyphoscoliosis with a deviation to the left in the thoracic and to the right in the lumbar spine, barrel chest, shortening of the cervical spine, macrocephaly, opal color of tooth enamel. Height $110 \mathrm{~cm}$, weight $55 \mathrm{~kg}$, BMl 45 $\mathrm{kg} / \mathrm{m} 2$; abdominal type of obesity. Patient could move only with the help of automatic wheelchair, as the result of severe 
deformations and shortening of the extremities. He required the help of a nurse or relatives for everyday activities.

According to the medical history, Ol was suspected at birth. From infancy, the patient was developing disproportionately with gradual formation of kyphoscoliosis and shortening of the limbs, which resulted in inability to walk. Since childhood, patient suffered from partial hearing loss, which progressed with age. At the age of 28 a hearing aid was installed dut to bilateral sensorineural hearing loss. Teeth issues also appeared in childhood: opal color of enamel, tooth crumbling. Fractures has been developing regularly since early childhood, with minimal physical impact, 10-12 times a year. Patient felt a «crack» noise at the site of fracture, accompanied by pain, swelling and bruising.

The patient underwent multiple musculoskeletal system assessments in different medical institutions. Nevertheless, he has been refusing to take suggested bisphosphonate treatment for several years because of personal reasons.

During his hospitalization at the Endocrinology Research Centre in 2014, a marked decrease in the lumbar vertebrae BMD (L1-L4 to $-4.2 S D$, with maximum decrease in L4 to -6.9SD Z-score) was revealed. To assess the number and severity of fractures, as well as the spine and thorax condition, we performed whole-body multispiral computed tomography (MSCT), which revealedmultiple vertebrae fractures with pronounced S-shaped right-left scoliosis, shortened long tubular bones, deformities of the pelvical and femoral bones, valgus deformity of the knee joints (Fig. 1). Signs of osteomalacia were most likely caused by vitamin $D$ deficiency, with normal values of phosphorus-calcium metabolism (Table 1). Ttubular bones calluses, which could be a confirmation of fractures, were not revealed, which can be explained by the high porosity of the skeleton and the difficulty of CT visualization.

Considering the deformation of the chest, immobilization of the patient, as well as medical history of chronic bronchitis, a cardiovascular system was examined. According to the echocardiography, left ventricular ejection fraction was $57 \%$, the ventricular myocardium wasn't thickened, the chambers of the heart were not dilated, no zones of myocardium asynergy were presented; signs of diastolic dysfunction of the ventricles and initial pulmonary hypertension were revealed. A cardiologist could not measure the patient's blood pressuredue to pronounced shortening of the extremities, but the the patient did not have left ventricle hypertrophy, it was possible to expect normal blood pressure. Taken together with the sinus rythm on the ECG,

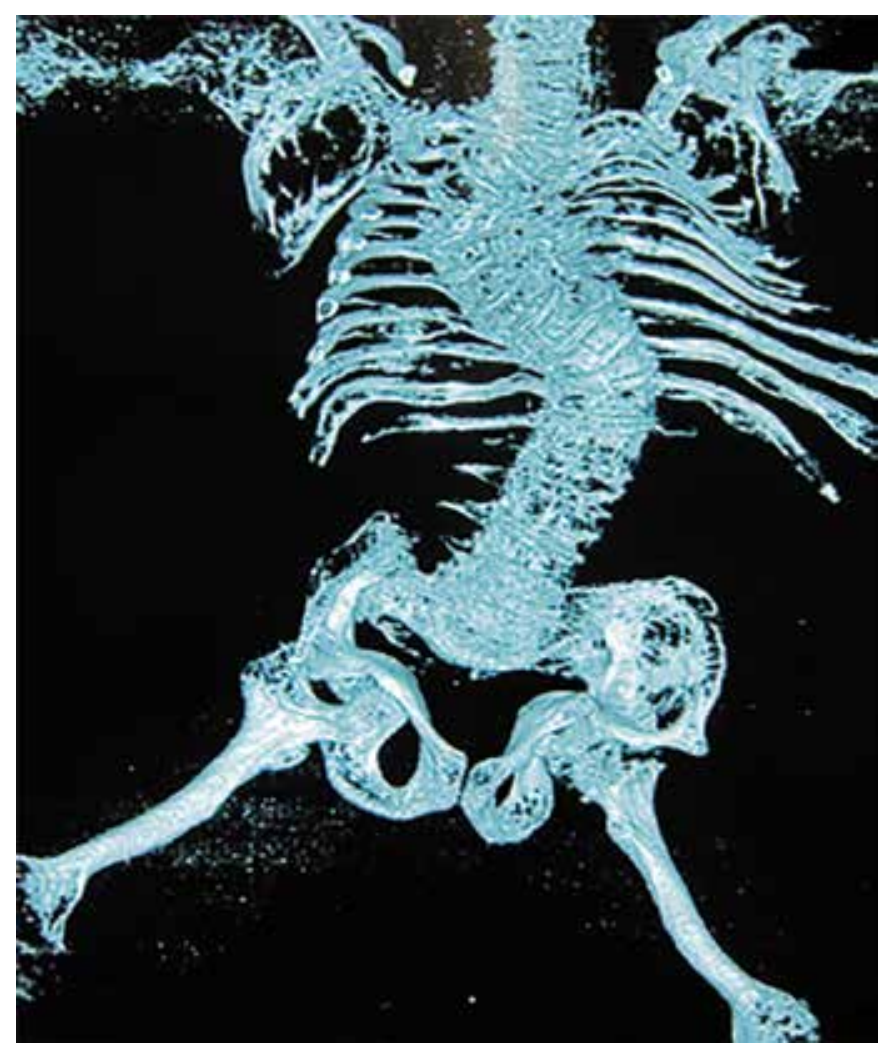

Fig. 1. Multispiral computed tomography of patient I.

these data suggested that the patient did not have significant cardiac disorders.

Progression of bone deformities, multiple bone fractures, which has been occuring since childhood, marked kyphoscoliosis, barrel chest, impairment of ossification and linear bone growth, as well as the impairment of teeth formation, hearing loss in adulthood - are common clinical features of type III OI. The diagnosis of type III OI was genetically confirmed in December 2014 - a heterozygous mutation c.2260G > T in the COL1A2 gene was found. Another identified heterozygous mutation c.2096G $>C$ in the LEPRE1 gene (the gene is associated with type VIII OI) was probably non-pathogenic.

In order to increase the BMD, decrease the severity of pain in the spinal cord and potentially reduce the risk of new fractures, we recommended the treatment with zoledronic acid $5.0 \mathrm{mg}$ in combination with calcium after correction of severe vitamin $D$ deficiency.

Table 1. Calcium, phosphorus and bone metabolism parameters of the patient I.

\begin{tabular}{|c|c|c|}
\hline Parameter & Result & $\begin{array}{c}\text { Reference } \\
\text { interval }\end{array}$ \\
\hline Total calcium (mmol/L) & 2,32 & $2,2-2,55$ \\
\hline lonized calcium (mmol/L) & 1,1 & $1,03-1,29$ \\
\hline Phosphorus (mmol/L) & 1,3 & $0,74-1,52$ \\
\hline PTH (pg/mL) & 10,42 & $15-65$ \\
\hline Vitamin D (ng/mL) & 13,2 & $30-100$ \\
\hline C-terminal telopeptide of type 1 collagen $(\mathrm{ng} / \mathrm{mL})$ & 0,305 & $0,01-0,69$ \\
\hline Osteocalcin (ng/mL) & 29,96 & $11-43$ \\
\hline
\end{tabular}


During the second hospitalization in Endocrinology Research Centre in November 2016, we noticed that the patient's condition deteriorated since 2014: he developed paroxysmal productive cough; physical examination revealed an umbilical hernia $8 \mathrm{~cm}$ in diameter. After talking to the patient, we found that he did not recieve the recommended treatment with zoledronic acid $5.0 \mathrm{mg}$ and calcium; patient was treated only with cholecalciferol in low doses. Wholebody MSCT showed progression of the spine deformity, signs of multiple rib fractures, atelectasis in the left lung S3, signs of infiltrative changes in the left lung S9-10, lower lobe of the right lung, with no change in heart configuration. ECG revealed sinus tachycardia with a heart rate of 102 beats / min; signs of a decreased blood supply to the myocardium in the anteroposterior region and the apex of the left ventricle. Productive paroxysmal cough was considered as a manifestation of chronic pharyngitis, appropriate treatment was prescribed. Patient was previously seen by a surgeon, who recommended surgical treatment for umbilical hernia.

Atraumatic fractures continued to occur regularly 1 time per month, back pain worsened; antiresorptive therapy was strongly recommended. Patient flatly refused suggested infusion of zoledronic acid $5.0 \mathrm{mg}$. Therefore, denosumab $60 \mathrm{mg}$ injection was administered subcutaneously as an alternative treatment. The patient was discharged, we recommended him to take calcium carbonate $1000 \mathrm{mg}$ / day, cholecalciferol 10,000 IU per week, denosumab 60 mg after 6 months. Considering the change in the configuration and volume of the left lung, as well as signs of right ventricular heart failure, we recommended the patient to visit a pulmonologist.

However, in this clinical case, antiresorptive treatment was administered untimely, after the development of pronounced kyphoscoliosis and the formation of a barrel chest that undoubtedly induced and accelerated the functional degradation of the internal organs and caused cardiopulmonary insufficiency, from which the patient died 6 months after he was discharged from the hospital.

\section{DISCUSSION}

McAllion and Peterson analysed 38 cases of death in III Ol patients and described life expectancy for this condition and causes of death. According to this study, in most cases death occurred in childhood or adolescence due to respiratory, cardiovascular or post-traumatic complications. The average life expectancy of patients with type III OI was 6.2 years (from 1 year to 28 years) [12].

In England, the structure of Ol patients mortality was analyzed based on observations of 743 patients between 1980 and 1993. In the group of patients with type I and IV Ol, there was no significant decrease in life expectancy, however, deaths at a young age occurred more often compared to healthy population. In type III OI, there was a very high mortality in childhood, and the risk of death after puberty also significantly exceeded the general population risk [13].

Another large study that estimated life expectancy and causes of death in a cohort of Ol patients was based on data from the Danish National Register from 1977 to 2013 [14]. The study included data on 687 patients with different types of OI, and a control group of 3435 people from the healthy population. The average life expectancy in a cohort of OI patients was 72.4 years for men (vs. 81.5 years in the con- trol group) and 77.4 years for women (vs. 84.5 years in the control group). In general, statistical analysis showed that the mortality rate (excluding the cause of death) was 3 times higher in Ol group, gender and age matched. Patients with Ol had a higher risk of dying from respiratory diseases, gastrointestinal diseases and fractures compared to a healthy population. The study of the register data, however, did not allow separate analysis for each type of OI, therefore the results of the work are averaged,as both mild and severe OI forms were included [14].

Despite different study design, it is obvious that life expectancy in patients with type III OI is much lower than in other non-lethal forms of the disease and compared with a healthy population, which is caused by cardiopulmonary insufficiency at a young age, as well as complications of multiple fractures.

For the last decades, in the world practice, as well as in Russia [7,15], Ol patients are being treated with bisphosphonates (BP) from childhood. BP increase BMD by reducing bone resorption, but does not affect collagen fibers. Dwan $\mathrm{K}$, et.al presented an analysis of studies and publications on treatment of OI [1]. Based on the results of this study, BP in OI does contribute to BMD increase, but there is no convincing evidence of fracture risk reduction in this cohort of patients. Moreover, according to the analysis, there is no observed reduction in clinical symptoms (reduction of pain, improvement in bone growth, increased mobility). Thus, the study of the efficacy and safety of prolonged BP therapy requires further study [1].

Besides that, there are attempts to treat Ol-induced osteoporosis with drugs with a different mechanism of action [16]. Teriparatide stimulates bone formation and promotes rapid increase in $\mathrm{BMD}$, but its effect on reducing fracture risk in a cohort of patients with Ol has not been studied [17-20]. In addition, its use in children is limited due to possible risk of neoplastic process. Denosumab is a human monoclonal antibody with affinity for receptor activator of nuclear factor kappa-B ligand (RANKL) [21]. It has been shown to be effective in the treatment of several children with type VI Ol, whereas due to special feature of the pathogenesis, BP treatment did not lead to an increase in BMD [22, 23]. However, there is currently no data on the safety of densumab in children with OI.

Ideal osteoporosis treatment in Ol should focus on increasing bone quality by improving the structural integrity of collagen. For this purpose, studies have been conducted using different in vivo laboratory models for bone marrow and mesenchymal stem cells transplantation for OI patients [22-24]. The first clinical trial included the treatment of OI children with mesenchymal stem cells transplantation from allogeneic bone marrow taken from siblings, which resulted an increase in growth rate and BMD and a decrease in fracture frequency 6 months after treatment $[25,26]$. Thus, the latest medical achievements open new possibilities for the treatment of hereditary bone diseases.

\section{CONCLUSION}

The mortality of Ol patients is higher than in general population and depends on the severity of connective tissue damage. The majority of deaths are associated with respiratory and cardiovascular diseases, which are primarily the re- 
sult of fractures and bone deformities of the chest, as well as post-traumatic complications. Antiosteoporotic treatment allows to increase BMD without strong evidence of fracture risk reduction. The drug effect on bone remodeling, with the help of cellular therapy, may prove to be a promising direction in the treatment of Ol.

It is necessary to note the importance of an integrated approach to the management of Ol, involving different specialists, including endocrinologists, cardiologists, pulmonologists and surgeons.

\section{ADDITIONAL INFORMATION}

The patient's informed consent. Official representatives of the patient signed volunrary informational agreement to publish anonymous personal medical data in medical journal Osteoporosis and Bone Diseases.

Conflict of interests. Authors declare no explicit and potential conflicts of interests associated with the publication of this article.

\section{СПИСОК ЛИТЕРАТУРЫ | REFERENCES}

1. Cole W. Advances in Osteogenesis Imperfecta. Clin Orthop Relat Res. 2002;401:6-16. doi: 10.1097/00003086-200208000-00003

2. Cole W. The Nicholas Andry Award-1996 The Molecular Pathology of Osteogenesis Imperfecta. Clin Orthop Relat Res. 1997;343:235-248. doi: 10.1097/00003086-199710000-00034

3. Brusin JH. Osteogenesis imperfecta. Radiol Technol. 2008;79(6):535-548.

4. Gonnelli S, Caffarelli C, Giordano N, Nuti R. The prevention of fragility fractures in diabetic patients. Aging Clin Exp Res. 2014;27(2):115-124. doi: 10.1007/s40520-014-0258-3

5. Steiner R, Adsit J, Basel D. COL1A1/2-Related Osteogenesis Imperfecta. Ncbin/mnihgov. 2018. Available at: https://www.ncbi.nlm.nih.gov/ books/NBK1295/. Accessed June 22, 2018

6. Sillence D, Rimoin D. Classification of osteogenesis imperfecta. The Lancet. 1978;311(8072):1041-1042. doi:10.1016/s01406736(78) $90763-8$

7. Белова Н.А., Костик М.М., Буклаев Д.С., и др. Федеральные клинические рекомендации (протокол) по оказанию медицинской помощи пациентам с несовершенным остеогенезом. - М., 2015. Доступно по httр://мороздгкб.рф/ wp-content/uploads/2017/03/Федеральные-клиническиерекомендации-протокол-по-оказанию-медицинской-помощипациентам-с-несовершенным-остеогенезом.pdf [Belova NA Kostik MM, Buklaev DS, et al. Federal'nye klinicheskie rekomendatsii (protokol) po okazaniyu meditsinskoj pomoshhi patsientam s nesovershennym osteogenezom. - Moscow; 2015. Available at: http://мороздгкб.pф/wp-content/uploads/2017/03/ Федеральные-клинические-рекомендации-протокол-пооказанию-медицинской-помощи-пациентам-с-несовершеннымостеогенезом.pdf. (In Russ).]

8. Glorieux FH. Osteogenesis imperfecta. Best Pract Res Clin Rheumatol. 2008;22(1):85-100

9. Eddeine H, Dafer R, Schneck M, Biller J. Bilateral Subdural Hematomas in an Adult with Osteogenesis Imperfecta. Journal of Stroke and Cerebrovascular Diseases. 2009;18(4):313-315. doi: 10.1016/j.jstrokecerebrovasdis.2008.11.008

10. Khandanpour N, Connolly D, Raghavan A, Griffiths P, Hoggard N. Craniospinal Abnormalities and Neurologic Complications of Osteogenesis Imperfecta: Imaging Overview. RadioGraphics. 2012;32(7):21012112. doi: $10.1148 /$ rg.327125716

11. van Dijk F, Cobben J, Kariminejad A et al. Osteogenesis Imperfecta: A Review with Clinical Examples. Mol Syndromol. 2011. doi: $10.1159 / 000332228$

12. McAllion S, Paterson C. Causes of death in osteogenesis imperfecta. J Clin Pathol. 1996;49(8):627-630. doi: 10.1136/jcp.49.8.627

13. Singer RB1, Ogston SA, Paterson CR. Mortality in various types of osteogenesis imperfecta. J Insur Med. 2001;33(3):216-20.

14. Folkestad L, Hald J, Canudas-Romo V et al. Mortality and Causes of Death in Patients With Osteogenesis Imperfecta: A Register-Based Nationwide Cohort Study. Journal of Bone and Mineral Research. 2016;31(12):2159-2166. doi: 10.1002/jbmr.2895
15. Белая Ж.Е., Рожинская Л.Я. Бисфосфонаты: мифы и реальность // Эффективная фармакотерапия. - 2010. - №38. - C. 52-59. [Belaya ZE, Rozhinskaya LY. Bisfosfonaty: mify i real'nost'. Effective Pharmacotherapy. 2010;(38);52-59. (In Russ).]

16. Dwan K, Phillipi CA, Steiner RD, et al. Bisphosphonate therapy for osteogenesis imperfecta. Cochrane Database Syst Rev. 2016;10:CD005088. DOI: 10.1002/14651858.CD005088.pub4

17. Bregou B, Aubry-Rozier B, Bonafé L, Laurent-Applegate L, Pioletti D, Zambelli P. Osteogenesis imperfecta: from diagnosis and multidisciplinary treatment to future perspectives. Swiss Med Wkly. 2016. doi:10.4414/smw.2016.14322

18. Белая Ж.Е., Рожинская Л.Я. Анаболическая терапия остеопороза. Терипаратид: эффективность, безопасность и область применения. // Остеопороз и остеопатии. - 2013. - Т. 16. - №2. - С. 32-40. [Anabolicheskaya terapiya osteoporoza. Teriparatid: ehffektivnost', bezopasnost' i oblast' primeneniya. Osteoporosis and Bone Diseases. 2013;16(2);32-40 (In Russ).] doi: 10.14341/osteo2013232-40

19. Gatti D, Rossini M, Viapiana O, et al. Teriparatide treatment in adult patients with osteogenesis imperfecta type I. Calcif Tissue Int. 2013;93(5):448-52. doi: 10.1007/s00223-013-9770-2

20. Orwoll ES, Shapiro J, Veith $S$, et al. Evaluation of teriparatide treatment in adults with osteogenesis imperfecta. J Clin Invest. 2014;124(2):4918. doi: 10.1172/JCI71101

21. Белая Ж.Е., Рожинская Л.Я. Новые направления в терапии остеопороза - применение моноклональных человеческих антител к RANKL (Деносумаб) // Остеопороз и остеопатии. 2011. - T. 14. - №2. - C. 23-26. [Belaya ZhE, Rozhinskaya LYa. Novye napravleniya $v$ terapii osteoporoza - primenenie monoklonal'nyh chelovecheskih antitel k RANKL (Denosumab). Osteoporosis and Bone Diseases. 2011;14(2):23-26. (In Russ).] doi: 10.14341/ osteo2011223-26

22. Hoyer-Kuhn $\mathrm{H}$, Netzer $\mathrm{C}$, Koerber $\mathrm{F}$, et al. Two years' experience with denosumab for children with osteogenesis imperfecta type VI. Orphanet J Rare Dis. 2014;9:145 doi: 10.1186/s13023-014-0145-1

23. Semler O, Netzer C, Hoyer-Kuhn H, Becker J, et al. First use of the RANKL antibody denosumab in osteogenesis imperfecta type VI. J Musculoskelet Neuronal Interact. 2012;12(3):183-8

24. Li F, Wang X, Niyibizi C. Bone marrow stromal cells contribute to bone formation following infusion into femoral cavities of a mouse model of osteogenesis imperfecta. Bone. 2010;47(3):546-55. doi: 10.1016/j. bone.2010.05.040

25. Guillot PV, Abass $\mathrm{O}$, Bassett $\mathrm{JH}$, et al. Intrauterine transplantation of human fetal mesenchymal stem cells from first-trimester blood repairs bone and reduces fractures in osteogenesis imperfecta mice. Blood. 2008;111(3):1717-25. doi: 10.1182/ blood-2007-08-105809

26. Vanleene M, Saldanha Z, Cloyd KL, et al. Transplantation of human fetal blood stem cells in the osteogenesis imperfecta mouse leads to improvement in multiscale tissue properties. Blood. 2011;117(3):1053-60. doi: 10.1182/blood-2010-05-287565 


\section{ИНФОРМАЦИЯ ОБ АВТОРАХ [AUTHORS INFO]}

Гребенникова Татьяна Алексеевна, к.м.н. [Tatiana A. Grebennikova, MD, PhD]; адрес: Россия, 117036, Москва, ул. Дм. Ульянова, д. 11 [address: 11 Dm.Ulyanova street, 117036 Moscow, Russia]; телефон: +79854831694; ORCID: http://orcid. org/0000-0003-1413-1549; eLibrary SPIN: 4380-5447; e-mail: grebennikova@hotmail.com

Малыгина Анастасия Андреевна, [Anastasia А. Malygina]; ORCID: https://orcid.org/0000-0002-4567-2412; eLibrary SPIN: 8990-8260; e-mail: malygina.aa@gmail.com

Белая Жанна Евгеньевна, Д.М.H., професcop [Zhanna E. Belaya, MD, PhD, Professor]; ORCID: http:// orcid.org/0000-0002-6674-6441; eLibrary SPIN: 4746-7173; e-mail: jannabelaya@gmail.com

Тюльпаков Анатолий Николаевич, д.м.н. [Anatoly N. Tiulpakov, MD, PhD]; ORCID: http://orcid.org/0000-0001-85004841; eLibrary SPIN: 8396-1798; e-mail: anatolytiulpakov@gmail.com

\section{ЦИТИРОВАТЬ:}

Малыгина А.А., Гребенникова Т.А., Тюльпаков А.Н., Белая Ж.Е. Несовершенный остеогенез как причина летального исхода. // Остеопороз и остеопатии. — 2018. - Т. 21. — №1. — C.23-27. doi: 10.14341/osteo9733

\section{TO CITE THIS ARTICLE:}

Malygina AA, Grebennikova TA, Tiulpakov AN, Belaya ZE. Osteogenesis imperfecta as a cause of death. Osteoporosis and bone diseases. 2018;21(1):23-27. doi: 10.14341/osteo9733 